\title{
Parents' understanding of gender towards parenting to teenagers
}

\author{
Demaris Cristina Sailana \\ Department of Anthropology \\ Faculty of Social and Political Sciences, Universitas Airlangga \\ Address: Jalan Dharmawangsa Dalam, Surabaya 60286 \\ E-mail: demariscristina.sailana@gmail.com
}

\begin{abstract}
Gender problems have become daily topics of discussion. The relationship between gender and parenting in a family can also cause different problems because the understanding among individuals in the family is also different. The purpose of this study was to determine the understanding of parents about gender and to identify the way parents provide parenting to boys and girls. The research method used in this study was a descriptive qualitative approach. The informants in this research were parents who have teenaged children, either boys or girls, or both of them. The results of this study indicate that parents in Claket Village did not understand the differences between gender and sex because they still distinguished the tasks based on sex. The way that the parents used to provide parenting to boys and girls was to involve their children directly in doing their parents' activities.
\end{abstract}

Keywords: understanding, gender, parenting

\section{Introduction}

Gender issues are an interesting topic of conversation that even become a global issue. That is the reason why gender becomes one of the actual news because the discussion does not finish in one problem. Gender and sex are often misunderstood; thus, in the practice, they create different social roles between men and women. In addition, they also cause imbalances where some parties are considered irrational and weak.

Family environment can be considered as the first place in shaping one's attitude. Consequently, in carrying out their duties and functions as a caregiver, parents are highly dependent on their understanding about gender. In providing parenting, parents often equalize gender and sex even though in fact, essentially, both words imply different meanings. Sex is the physical differences that naturally distinguish male and female, while the concept of gender is the difference in social status that is created by humans and ingrained in the society.

Parents play a major role in shaping someone to be masculine and feminine because gender is the result of socialization provided to teenage boys and girls through parenting instead of being caused by gender differences. Therefore, it is very important for parents to understand the differences in the concept of gender and sex so that there is no difference in treatment or provision of privileges for one sex because the parents' understanding will be shown in the way the parents treat and provide an understanding of values to teenage boys and girls related to their duties and functions in the family and society.

Fakih (2008) defined gender as the inherent nature of men and women that is constructed socially and culturally. Gender is the division between men and women in the roles, functions, rights, responsibilities and behaviors that are formed by the social, cultural and cultural values of community groups that can change according to the local time and conditions. Responsibilities and behaviors are shaped by social, cultural and traditional values of community groups that can change according to local time and conditions (Puspitawati 2009).

In general, sex is used to identify differences between men and women from biological anatomy, while gender concentrates more on the social, cultural, and other non-biological aspects. Sex study 
emphasizes more on the development of biological aspects and chemical composition in the body of a man and a woman. On the other hand, gender study emphasizes the development of a masculinity and femininity aspects of a person (http://riskinavi.blogspot.com/2016/05/gender-dan-feminisme.html).

As a result, gender does not refer to biological characteristics that are naturally inherent, but it refers to the understanding of society. Gender differences occur due to different views in the society so that they become socially accepted norms. Gradually, however, the views of the society will continue to develop in accordance with the knowledge and experience. Ergo, it will change the gender understanding of the society in accordance with the development and views of the society.

Norm system that applies in the society goes along with the time. Knowledge about gender has been a legacy from generation to generation. Without further considerations, gender applies in daily life. Thus, it is finally regarded as a natural and irreversible trait. As a result, gender differences are considered and understood as the nature of men and women that do not need to be questioned. Such views of society cause a misperception of the meaning of sex and gender. Often, people assume that sex and gender are the same by interpreting that gender is sex.

Apart from the problem above, parents who have teenage children in Claket Village, Pacet District, Mojokerto, have little understanding about gender. Consequently, culture has a major role in shaping parents' understanding about gender because the lack of parents' understanding about gender has some impacts on the parenting for teenage boys and girls. The purpose of this article is to ascertain parents' understanding of gender and identify the parenting that is provided to both teenage boys and girls.

\section{Method}

This article employed a descriptive approach to explain parents' understanding about gender in applying parenting. In this article, the focus of the problem was to inform the experience of the parents' tasks during their adolescence to teenage boys and girls. The information covered the parents' knowledge about the distribution of tasks to teenage boys and girls, the parents' way to socialize gender (social roles) to teenage boys and girls, and the parents' way to provide information about the tasks of teenage boys and girls. The data collection utilized interview, observation and literature study techniques. Then, data reduction, data presentation and conclusion drawing were employed to analyze the data.

\section{The Research Result and Discussion}

Parents in Claket Village gave tasks to teenage boys and girls according to their sex and parents' experience as a teenager. From the results of interviews conducted by the researchers with IR on Wednesday, October 5, 2017 at 10:00 to 11:40 WIB, the result is as follows:

"Kami memberi pemahaman gender kepada anak laki-laki dan perempuan sesuai dengan kebiasaan orang tua kami dulu. Laki-laki tidak boleh lemah seperti perempuan dan perempuan tidak boleh berperilaku seperti laki-laki. Orang tua kami membedakan laki-laki itu tugasnya lain dan tugas anak perempuan itu lain juga. Karena itu sudah jadi tradisi kami makanya gitu juga kami ajarkan pada anak kami sekarang dan sesuai dengan adat disini".

(We give understanding about gender to boys and girls in accordance with the habits of our parents in the past. Men shouldn't be weak like women and women shouldn't behave like men. Our parents emphasized the differences of a man's duties and a woman's duties. Because it has become our tradition, then, that's also the way we teach our children now that is based on the custom here.)

IR's description above shows that parents provides socialization to teenage boys and girls in accordance with parents' experiences when they were teenagers; hence, experience becomes a 
reference for distinguishing tasks between teenage boys and girls. Parents give socialization to teenage girls and boys according to what they experienced and felt. Then, it is descended to their children.

The results showed that in terms of scientific knowledge, parents did not understand the differences between gender and sex yet because parents' understanding about gender was influenced by their experience and customary values. People's understanding about gender was highly dependent on local experience and culture. Therefore, the tasks assigned to teenage boys and girls were based on their parents' experiences (Ummah 2011).

Parents' experience about tasks was then passed on to their teenager children because they did not understand about gender yet. Parents who do not understand about gender provide socialization of tasks to teenage boys and girls in accordance with their previous experience. Therefore, parents tended to give socialization of task division to teenage boys and girls according to the tradition in Claket Village.

The parents did not understand about the differences between gender with sex. Therefore, they differentiated tasks between teenage boys and girls based on sex. Parents only had the knowledge that the duties of teenage boys were different from the duties of teenage girls. This understanding makes parents provide the outdoor work to teenage boys while the girls' duties are directed to the indoor ones.

Parents provided socialization of the tasks to teenage boys and girls. The socialization was carried out by parents to teenage boys and girls in the hope that their children would learn and understand about the tasks they would do when they were adults as explained in the Nature theory that women were born as women with physical appearance, physical function and social roles. Women are physically different from men, as stated by Muthali' in (2001) that men have a stronger physical stature constructed to play a role in the public sector, and to face the rigors of life, while at the same time, to provide protection to the weaker parties, i.e. women.

Parents conveyed the tasks that had to be carried out to their children because by doing so, their children will understand that the tasks of teenage boys and girls are distinguished by sex. The socialization of the duties from parents to children will form children's understanding of the different works between men and women. National Population and Family Planning Board/BKKBN team (2004) explains that the nurture (culture) theory views the differences between women and men essentially due to the result of sociocultural construction; hence, there are different roles and tasks and these differences cause women to always be left behind and their roles and contributions in family life, society, nation, and state are also neglected.

The way that the parents used to provide parenting to teenage boys and girls was by involving their children directly in every work performed by parents because by involving teenage boys and girls in the work, naturally the children will understand about the division of tasks between teenage boys and girls. Parents' parenting was utilized in attempting various strategies to encourage children to achieve the desired goals, such as knowledge, moral values, and behavioral standards that should be possessed by the children when adult (Mussen et al. 1994).

Differences of tasks between teenage boys and girls affect the parenting where parents forbid girls from going out at night like teenage boys and parents have restricted certain attitudes and behaviors to teenage boys and girls. Therefore, parenting practices lead to authoritarian parenting, i.e. parents who tend to set absolute standards that must be abode, along with the threats (Baumrind 1991).

In addition, parents distinguish their parenting to teenage boys and girls by sex. In this case, the freedom of teenage girls is restricted and they must not behave like boys, while boys are given more freedom but forbidden to behave like girls. Gender differences are seen as a socio-cultural construction in which the differences in the social roles of men and women are not natural (Suryadi \& Idris 2004). 


\section{Conclusion}

The understanding of several parents in Claket Village was lack regarding the concept of gender since parents still distinguished the work between teenage boys and girls based on sex, where parents provided socialization about their experience on carrying out the tasks they had done to their teenage boys and girls. The division of tasks to teenage boys and girls, which was in accordance with the experience of parents, showed that the parents in the Claket Village did not understand about the concept of gender because the tasks they assigned to their teenage boys and girls had been descended for generations. Based on the parents' knowledge in regards to the division of tasks between teenage boys and girls, the tasks were divided according to sex. Therefore, parents assigned the outdoor and heavy tasks for teenage boys, while the teenage girls received all the indoor tasks.

Parents in Claket Village provided socialization about the activities of the tasks that they carried out to their teenage boys and girls, the purpose of which was to make the teenage girls and boys understand that there were differences in the tasks between men and women. The way parents provided parenting to teenage boys and girls in Claket Village was by involving their children directly in carrying out the parents' work because by doing so, the children could understand what the tasks of women were and what the duties of men were. In addition to differences in sex-based duties, parents have set certain standards of behavior and freedom for teenage boys and girls. In this regard, parents forbade girls from behaving like men and vice versa. Moreover, parents forbade teenage girls from going out at night like teenage boys.

\section{References}

Baumrind D (1991) The influnce of parenting style on adolescent and substance use. The Journal of early adolescent 11 (1): 56-95.

Fakih M (2008) Analisis gender dan transformasi sosial. Yogyakarta: INSIST Press.

Mussen PH, Conger JJ, \& Huston AC (1994) Perkembangan dan kepribadian anak. Jakarta: Arcon Noor.

Muthali'in A (2001) Bias gender dalam pendidikan. Surakarta : Universitas Muhammadiyah Press.

Puspitawati H (2009) Teori Gender dan Aplikasinya Dalam Kehidupan Keluarga. Bogor: Institut Pertanian Bogor Press.

Riskinavi (2016) Gender dan feminisme. [Diakses 1 Desember 2017] http://riskinavi.blogspot.com/2016/05/gender-dan-feminisme.html.

Suryadi A \& Idris E (2004) Kesetaraan Gender Dalam Bidang Pendidikan. Jakarta: PT Genesindo.

Tim BKKBN (2004) Bunga Rampai Panduan dan Bahan Pembelajaran Pelatihan Pengarusutamaan Gender dalam Pembangunan Nasional. Jakarta: KPP dan PA, BKKBN, UNFPA.

Ummah AF (2011) Sikap otoriter orangtua dan pengaruhnya terhadap motivasi belajar siswa MTS Al Hidayah Jatiasih Kota Bekasi. Skripsi, UIN Syarif Hidayatullah, Jakarta. 